\section{Some Recent}

\section{Highlights in Gold Chemistry}

\section{Concepción Gimeno and Antonio Laguna}

Departamento de Química Inorgánica. Instituto de Ciencia de Materiales de Aragón. Universidad de Zaragoza-C.S.I.C. E-50009 Zaragoza, Spain. E-mail: gimeno@unizar.es, alaguna@unizar.es

\section{Introduction}

As the readers of Gold Bulletin know gold is a unique element. It has been present in man's life since the earliest civilisations and has occupied an important place in the history of mankind for over 7000 years, as we can see from the excellent goldsmith works found, for instance, in the Minoic, Egyptian or South American tombs. Its chemistry is also different to that of the other metals, and main differences are the consequence of the relativistic effects, which are especially important for gold.

a) There is a contraction of the $6 \mathbf{s}$ orbitals and this stabilisation explains the great stability of the metallic state and the ease of formation of the auride anion.

b) The $\mathbf{5 d}$ orbitals undergo an expansion and this destabilisation leads to the efficient formation of the (III) oxidation state in gold, or even higher oxidation states.

c) Other consequence of these relativistic effects is the colour of gold. Gold has an absorption beginning at 2.4 $\mathrm{eV}$, attributed to a transition from the filled $\mathbf{5} \mathbf{d}$ band to the Fermi level (essentially the $\mathbf{6 s}$ band). It therefore reflects red and yellow light and strongly absorbs blue and violet.

d) The covalent radius of gold is smaller than of silver, in about 0.09(1) $\AA$, as it has been recently confirmed in the isomorphous two-coordinated complexes $\left[\mathrm{M}\left(\mathrm{PMes}_{3}\right)_{2}\right] \mathrm{BF}_{4}$ ( $M=A g, A u ;$ Mes = mesithyl) (1).

e) The closed shell $\mathbf{5} \mathbf{d}^{\mathbf{1 0}}$ is no longer chemically inert and can interact with other elements, i.e., with other gold atoms in molecules or clusters. It also becomes possible to rationalise bonding between two gold(I) centres with equal charge and a closed shell $\mathbf{5} \mathbf{d}^{10}$ configuration, which is a difficult fact to explain in terms of classical bonding. Gold(I) centres try to be as close as possible to each other and generally the Au-Au distances (between 2.7 and $3.3 \AA$ ) are even shorter than the ones found in metallic gold. This effect has been called aurophillic attraction or aurophilicity (2) by Schmidbaur.
Theoretical calculations, including relativistic effects, have played a key role in understanding this unique behaviour and the development of gold chemistry. These calculations have shown that bonding between closed-shell metal centres may be strongly enhanced by the relativistic effects $(3,4)$, and aurophilicity was accepted as a logical consequence of these contributions.

All these factors have contributed to a continuous expansion of gold chemistry, mainly since the early 1980s; not only well-established areas of research have developed but also new innovative approaches have allowed a great diversification of the research interests. We include in this micro-review some highlights in gold chemistry published during the last two decades.

\section{High oxidation states}

In oxidation states higher than III, we know of a few examples with very electronegative ligands. The yellow crystalline AuF is prepared by disproportionation of $\mathrm{AuF}_{6}$ (obtained by oxidation of $A u F_{5}$ with fluorine) and can be isolated at $-196^{\circ} \mathrm{C}$ (5). The pentafluoride AuF $_{5}$ is formed by vacuum pyrolisis of either $[\mathrm{KrF}]\left[\mathrm{AuF} \mathrm{F}_{6}\right]$ or $\left[\mathrm{O}_{2}\right]\left[\mathrm{AuF}_{6}\right]$ (6). The crystal structure reveals that AuF $_{5}$ exists as a dimer in the solid state (7). Salts of $\left[\mathrm{AuF}_{6}\right]^{-}$ with different cations, including $\mathrm{Ag}^{+}$, are also known (8).

The evidence for the existence of the oxidation state IV is not yet totally convincing. Some complexes with dithiolene or dithiolate, such as [Au(5,6-dihydro-1,4-dithiin-2,3dithiolate) 2] (9) or [Au(2,3-dithiophenedithiolate)2] (10), have been prepared by chemical or electrochemical oxidation of the corresponding gold(III) derivatives. However, the molecular orbital calculations suggest that the metal ions of the molecules are best described as Au(III), and therefore the unpaired electron is delocalised on the ligands.

\section{Gold(III) complexes}

Gold(III) gives stable complexes with N, S, P, C donor ligands and also with oxygen-based ligands. The geometry is generally square planar but with bidentate ligands a pseudopentacoordination can be achieved. Some relevant contributions in this field are:

The synthesis of dinuclear ylide complexes, such as $\left[\mathrm{Au}_{2} \mathrm{X}_{4}\left\{\left(\mathrm{CH}_{2}\right)_{2} \mathrm{PR}_{2}\right\}_{2}\right] \quad(\mathrm{X}=\mathrm{Cl}, \mathrm{Br}, \quad \mathrm{l} ; \mathrm{R}=\mathrm{Me}, \mathrm{Ph})$ or $\left[\mathrm{Au}_{2} \mathrm{X}_{3}\left(\mathrm{CH}_{2} \mathrm{X}\right)\left\{\left(\mathrm{CH}_{2}\right)_{2} \mathrm{PR}_{2}\right\}_{2}\right]$, by oxidation with two equivalents of halogens or thionyl chloride, of the corresponding gold(I) derivatives; that leads generally to the trans, trans-isomer (1), but also the cis, trans- and cis, cis-derivatives (2) have been reported $(11,12)$. Also complexes with an halogen bridging ligand, such as $\left.\left[\mathrm{Au}_{2} \mathrm{Br}_{2}(\mu-\mathrm{Br})\right)\left\{\left(\mathrm{CH}_{2}\right)_{2} \mathrm{PPh}_{2}\right\}_{2}\right] \mathrm{IBr}_{2}(3)$ have been obtained (12). 


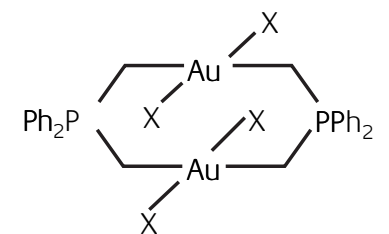

(1)

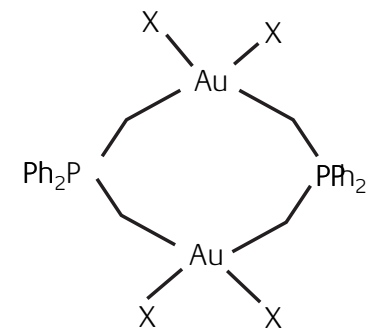

(2)

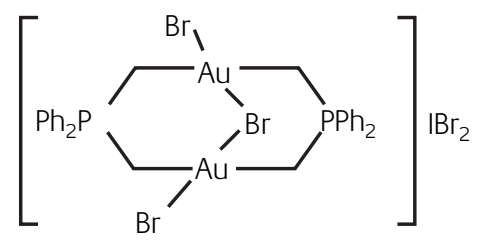

(3)

Box 1. Gold(III) ylide complexes

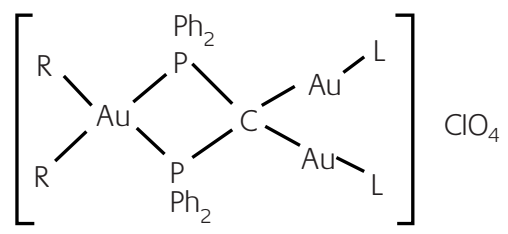

(4)<smiles>[R][Al]([R])([R])P1[PH2]P1c1ccccc1</smiles>

(5)<smiles></smiles>

(6)

Box 2. Gold $(I I I)$ methanide $\left(R=C_{6} F_{5}\right)$ and cycloaurated complexes

The reaction of cis-[Au( $\left.\left(\mathrm{C}_{6} \mathrm{~F}_{5}\right)_{2}\left\{\left(\mathrm{PPh}_{2}\right)_{2} \mathrm{CH}_{2}\right\}\right] \mathrm{ClO}_{4}$ with $\mathrm{NaH}$ causes deprotonation of the methylene group and formation of $\left[\mathrm{Au}\left(\mathrm{C}_{6} \mathrm{~F}_{5}\right)_{2}\left\{\left(\mathrm{PPh}_{2}\right)_{2} \mathrm{CH}_{2}\right\}\right]$. This (phosphino)methanide complex can act as $\mathrm{C}$-donor nucleophile in the reactions with some
gold(I) derivatives to form di- or trinuclear complexes. The use of acetylacetonate complexes allows the double deprotonation of the methylene group and the coordination of two gold $(\mathrm{I})$ centres to the methanediide $\mathrm{C}$ atom, as in $\left[\mathrm{Au}\left(\mathrm{C}_{6} \mathrm{~F}_{5}\right)_{2}\left\{\mathrm{PPh}_{2} \mathrm{C}\right.\right.$ $\left.\left.\left(\mathrm{AuPPh}_{3}\right)_{2} \mathrm{PPh}_{2}\right\}\right] \mathrm{ClO}_{4}(4)$ (13). In $\left[\mathrm{Au}\left(\mathrm{C}_{6} \mathrm{~F}_{5}\right)_{2} \mathrm{Cl}\left\{\mathrm{PPh}_{2} \mathrm{C}\left(=\mathrm{CH}_{2}\right) \mathrm{PPh}_{2}\right\}\right]$, the coordination of the vinylidenebis(diphenylphosphine) to the gold(III) centre strongly activates the carbon-carbon double bond, and this complex therefore, undergoes Michael-type additions with several carbon, sulfur or oxygen based nucleophiles to form a new type of methanide complexes (14), as $\left[\mathrm{Au}\left(\mathrm{C}_{6} \mathrm{~F}_{5}\right)_{2}\left\{\mathrm{PPh}_{2} \mathrm{C}\left(\mathrm{CH}_{2} \mathrm{SPh}\right) \mathrm{PPh}_{2}\right\}\right](\mathbf{5})$.

An important number of cycloaurated complexes have been described during the last years. Most of the ligands that give this type of compound are pyridine derivatives. The reaction of $\left[\mathrm{AuCl}_{4}\right]^{-}$with substituted pyridines $(\mathrm{N}, \mathrm{C})$ (15), such as phenylpyridine or (alkylsulfanyl)pyridine, among others, at room temperature yield the non-metallated compounds $\left[\mathrm{AuCl}_{3}(\mathrm{~N}, \mathrm{C})\right]$, which, upon heating, are transformed into the metallated complexes $\left[\mathrm{AuCl}_{2}(\mathrm{~N}, \mathrm{C})\right](\mathbf{6})$. Some of these compounds have been reported to show antitumor activity (16).

Cold(III) complexes with macrocyclic ligands are also of interest. Bis(ethylenediamine)gold(III) chloride reacts with $\beta$ diketonates in aqueous base via a Schiff base condensation to form complexes of gold(III) with a 14-membered macrocyclic tetraza ligand (17). A new method for the incorporation of gold(III) into porphyrins (7) has been described and consist of the disproportionation of $\left[\mathrm{Au}(\mathrm{tht})_{2}\right] \mathrm{BF}_{4}$ in mild conditions (18). Gold(III) porphyrins have been used as acceptors in porphyrin diads and triads due to their ability to be easily reduced, either chemically or photochemically (19).

Although the chemistry of phosphido-bridged transition metal complexes is well represented, the corresponding gold chemistry has only recently developed. The diphenylphosphino derivatives $\left[\mathrm{Au}\left(\mathrm{C}_{6} \mathrm{~F}_{5}\right)_{3}\left(\mathrm{PPh} \mathrm{H}_{2} \mathrm{H}\right)\right]$ or $\left[\mathrm{Au}\left(\mathrm{C}_{6} \mathrm{~F}_{5}\right)_{2}\left(\mathrm{PPh}_{2} \mathrm{H}\right)_{2}\right] \mathrm{ClO}_{4}$ react with acetylacetonate compounds to give polynuclear derivatives with phosphido-bridged ligands (20), such as complex 8 .

The treatment of $\mathrm{Bu} 4 \mathrm{~N}\left[\mathrm{AuBr}\left(\mathrm{C}_{6} \mathrm{~F}_{5}\right)_{3}\right]$ with $\mathrm{NaSH}$ leads to the first (hydrosulfido)gold(III) compound $\mathrm{Bu} 4 \mathrm{~N}\left[\mathrm{Au}\left(\mathrm{C}_{6} \mathrm{~F}_{5}\right)_{3}(\mathrm{SH})\right]$, that readily reacts with $\left[\mathrm{Au}\left(\mathrm{C}_{6} \mathrm{~F}_{5}\right)_{3}\left(\mathrm{OEt}_{2}\right)\right]$ to give $\mathrm{Bu}_{4} \mathrm{~N}\left[\left\{\mathrm{Au}\left(\mathrm{C}_{6} \mathrm{~F}_{5}\right)_{3}\right\}_{2}(\mathrm{SH})\right]$ (9); the isolobal analogy existing between hydrogen and the fragments $\left[\mathrm{AuPR}_{3}\right]^{+}$or $\left[\mathrm{AgPR}_{3}\right]^{+}$can be envisaged in the synthesis of the substituted derivatives Bun $\left[\mathrm{Au}\left(\mathrm{C}_{6} \mathrm{~F}_{5}\right)_{3}\left(\mathrm{SMPPh}_{3}\right)\right](\mathrm{M}=\mathrm{Au}, \mathrm{Ag})$ (21). Polynuclear sulfur and selenium centred complexes have been described by reaction of $\left[X\left(\mathrm{AuPPh}_{3}\right)_{2}\right]$ or $\left[\mathrm{X}\left\{\mathrm{Au}_{2}(\mu-\right.\right.$ $\mathrm{dppf}$ )\}] (dppf = bis(diphenylphosphino)ferrocene, $\mathrm{X}=\mathrm{S}$, Se) with gold(III) complexes. The complexes thus obtained, as 10 , have the sulfur or selenium atoms as triply or quadruple bridging ligands. Weak gold(I)-gold(III) interactions have been observed in the triply bridging complexes and theoretical studies show that although weaker than gold(I)gold(I) there exist gold(I)-gold(III) interactions (22). 


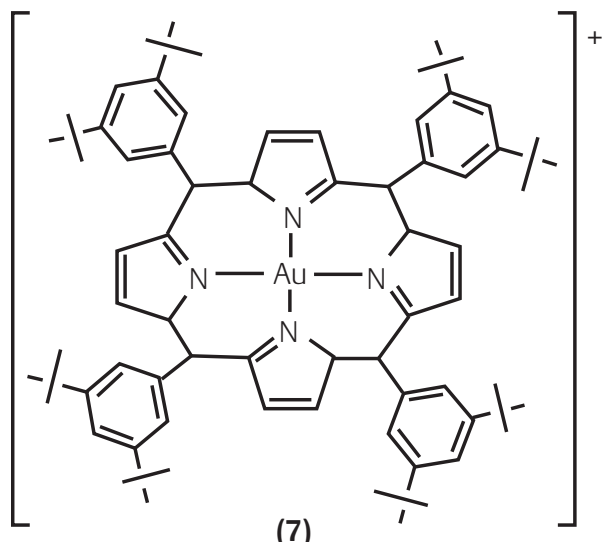

(7)

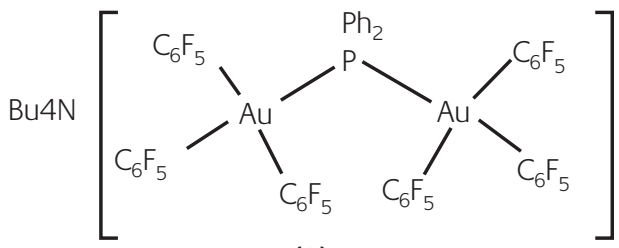

(8)

Box 3. Gold(III) porphyrin and phosphido-bridged complexes

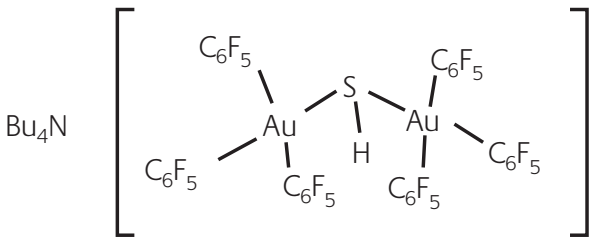

(8)

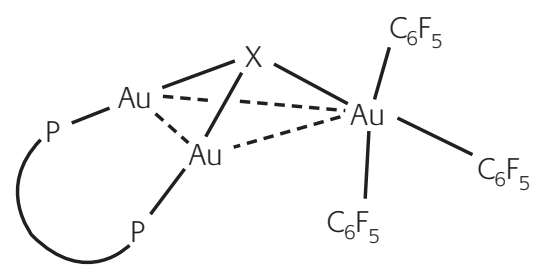

(10)

Box 4. Gold(III) sulfur and selenium centred complexes $(\mathrm{P}-\mathrm{P}=\mathrm{dppf}, \mathrm{X}=\mathrm{S}, \mathrm{Se})$

Some gold(III) derivatives as catalysts have been employed, for example gold(III) halides have been used to catalysed C-C and C-O coupling reactions (23)

\section{Gold(II) complexes}

The chemistry of paramagnetic mononuclear gold(II) species is not very extensive because most of them are prepared by reduction of the gold(III) species with ligands able to delocalise electron density, such as dithiocarbamates, dithiolates, etc. However, the number of complexes with gold in a formal oxidation state of two has increased during the last decade. A precisely characterised complex is the mononuclear $\left[\mathrm{Au}\left([9] \mathrm{aneS}_{3}\right)_{2}\right]\left(\mathrm{BF}_{4}\right)_{2}$ (11), obtained by reduction of $\mathrm{HAuCl}_{4} \cdot 3 \mathrm{H}_{2} \mathrm{O}$ with two equivalents of [9] anes $S_{3}$ in refluxing $\mathrm{HBF}_{4} / \mathrm{MeOH}$. The gold centre is surrounded by six sulfur atoms in an octahedral disposition, with a Jahn-Teller distortion (24). The first metal-xenon compound, $\left[A u X_{4}\right]\left(\mathrm{Sb}_{2} \mathrm{~F}_{11}\right)_{2}$ (12) obtained by reduction of $\mathrm{AuX}_{3}$ with elemental xenon deserves special mention. Surprisingly the reaction stops at the $A u(I)$ state and result in a completely unexpected complex. The geometry of the cation is square planar and the bonding between gold and xenon is of the $\sigma$ donor type, with a charge of approximately 0.4 per xenon atom. Removal of gaseous xenon under vacuum results in the crystallization of $\mathrm{Au}\left(\mathrm{SbF}_{6}\right)_{2}$ (25). By a variation of the xenon pressure other $\mathrm{Au}(\mathrm{II})$-Xe compounds, such as cis-[AuXe $\left.]_{2}\right]\left[\mathrm{Sb}_{2} \mathrm{~F}_{11}\right]_{2}$ (13), have been isolated (26). Relativity plays a large role in stabilizing this and other predicted Au-Xe compounds; about half of the Au-Xe bonding energy comes from relativistic effects (27).

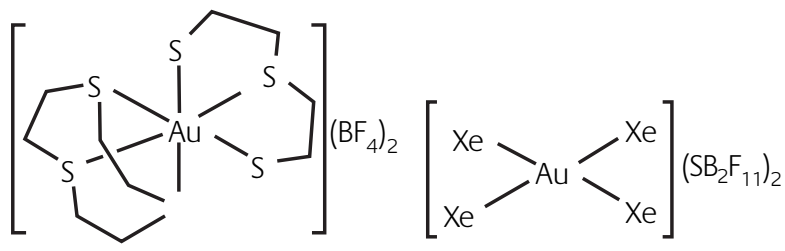

(11)

(12)

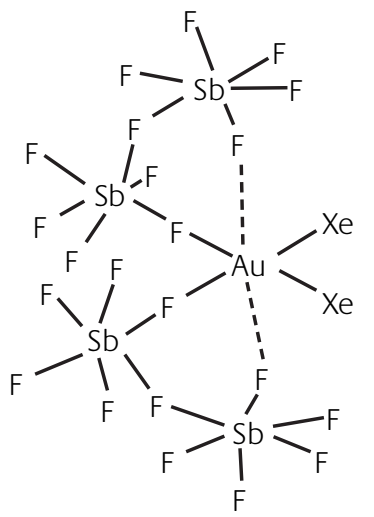

(13)

Box 5. Mononuclear Gold(II) complexes

One of the reasons for the poor stability of gold(II) complexes is the unfavourable energy of the odd electron. The formation of a metal-metal bond in dinuclear gold(II) complexes giving diamagnetic species provides extra stability. A rich chemistry on dinuclear diamagnetic gold(II) derivatives has been carried on bis(ylide) gold(II) species, $\left[\mathrm{Au}_{2} \mathrm{X}_{2}(\mu-\right.$ $\left.\left.\left(\mathrm{CH}_{2}\right)_{2} \mathrm{PPh}_{2}\right\}_{2}\right]$ (14) (28); they have a great stability that allows 
a great variety of substitution reactions. Most of the dinuclear gold(II) compounds are synthesised from the corresponding gold(I) precursors by oxidative addition of a halogen. Some examples of dinuclear gold(II) derivatives are in Box 6, including a complex with a cyclometallated phosphine (15) (29), and other without bridging ligands (16) (30).

Interesting results have been described in the oxidation of the polynuclear $\left[\mathrm{Au}_{2}\left\{\mu-\left(\mathrm{PPh}_{2}\right)_{2} \mathrm{CHAu}\left(\mathrm{C}_{6} \mathrm{~F}_{5}\right)\right\}_{2}\right]$ or $\left[\mathrm{Au}_{2} \mathrm{Pt}(\mu-\right.$ $\left.\mathrm{CH}_{2} \mathrm{PPh}_{2} \mathrm{~S}\right)_{2}$ ] with halogens (molar ratio $1: 1$ ). In the first case, a new type of reaction occurs and complex 17, with an almost lineal X-Au-Au-Au-X chain, was obtained (31). In the second one, complex $\mathbf{1 8}$ was formed, with a lineal Cl-Au-Pt$\mathrm{Au}-\mathrm{Cl}$ chain (32). The reaction of the gold(II) complexes $\left[\mathrm{Au}_{2}\left\{\mu-\left(\mathrm{CH}_{2}\right)_{2} \mathrm{PR}_{2}\right\}_{2} \mathrm{R}(\mathrm{tht})\right]^{+}$or $\left[\mathrm{Au}_{2}\left\{\mu-\left(\mathrm{CH}_{2}\right)_{2} \mathrm{PR}_{2}\right\}_{2} \mathrm{R}\left(\mathrm{OClO}_{3}\right)\right](\mathrm{R}=$ $\left.\mathrm{C}_{6} \mathrm{~F}_{5}, 2,4,6-\mathrm{C}_{6} \mathrm{~F}_{3} \mathrm{H}_{2}\right)$ with $\mathrm{Bu}_{4} \mathrm{~N}\left[\mathrm{AuR}_{2}\right]$ leads to the synthesis of gold chain complexes, as 19 (33).

\section{Gold(I) complexes}

Gold $(I)$ is by far the most studied oxidation state of this metal. Although the $[\mathrm{AuCl}(\mathrm{CO})]$ complex has been known since 1925 , only recently the linear dicarbonyl cation $\left[\mathrm{Au}(\mathrm{CO})_{2}\right]^{+}$has been obtained as thermally stable $\mathrm{UF}_{6}{ }^{-}$or $\mathrm{Sb}_{2} \mathrm{~F}_{11}{ }^{-}$salts, by oxidation of metallic gold with $\mathrm{UF}_{6}$ or carbonilation of $\left[\mathrm{Au}\left(\mathrm{SO}_{3} \mathrm{~F}\right)(\mathrm{CO})\right]$ in pure $\mathrm{SbF}_{5}$, respectively (34). In these compounds back-bonding to $\mathrm{CO}$ is almost entirely absent.

The most striking phenomenon was the tendency of the linear gold(I) compounds to associate in dimers, oligomers or even polymers via short gold(I)-gold(I) interactions (35). These attractions are weaker than most covalent or ionic bonds, but stronger than other van der Waals and comparable in strength to typical hydrogen bonds, ca. 33 $\mathrm{kJ} / \mathrm{mol}$. The most convincing example of aurophilicity is found in polyaurated molecules. Double auration at halide anions to give $\mathbf{V}$-shaped cations with small angles, as complex $\mathbf{2 0}$, for chloride and bromide is known (36). Oxide anions can accept up to four gold atoms to give tetrahedral complexes (complex 21) (37). Sulfide, selenide and telluride anions can reach coordination numbers from 2 to 6 , and the resulting complexes have structures clearly determined by Au-Au interactions (as in 22, E = S or Se) (38). Nitrogen became pentacoordinate (39), phosphorus hexacoordinate (40) and arsenic tetracoordinate (41) in homoleptic phosphine species. Carbon was one of the first examples of polyauration and pentacoordinate and hexacoordinate compounds (as 23) have been described (42). Other polyaurated complexes have also been described with several ligands containing these atoms, such as alkoxides, thiolates (43), selenolates, amines (as complex 24) (44), methanides (45), borides (as complex 25) (46), etc. Other examples of homo- (as 26) (47) or heteropolynuclear complexes (as 27 ) (48) have been reported.<smiles></smiles>

(14)

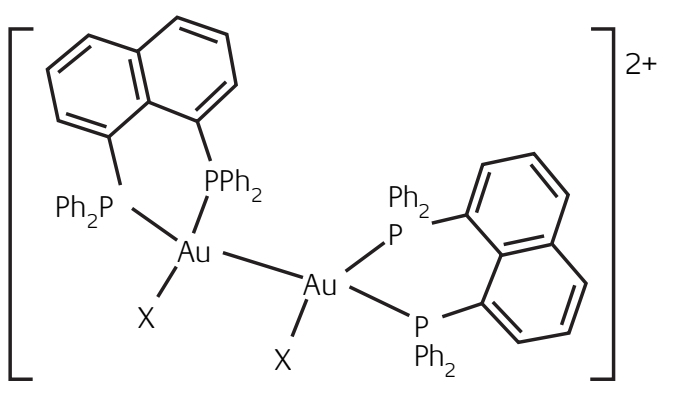

(16)

Box 6. Dinuclear Gold(II) complexes

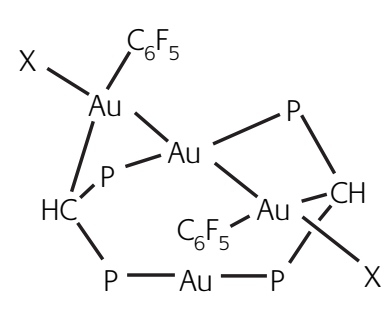

(17)

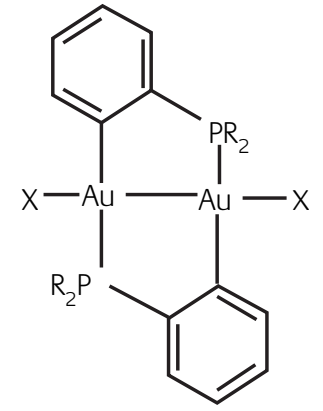

(15)

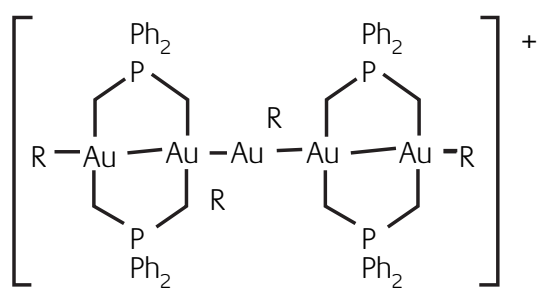

(19)

Box 7. Polynuclear Gold(II) complexes

The presence of this interatomic attractive force due to the gold-gold interactions seems to determine, at least in part, molecular configurations and crystal lattices of gold(I) complexes. Some examples are the dinuclear (chloro)gold(I) complexes of ditertiary phosphines of the type $\left[\mathrm{Au}_{2} \mathrm{Cl}_{2}\{\mu\right.$ $\left.\left.\left(\mathrm{PPh}_{2}\right)_{2}\left(\mathrm{CH}_{2}\right)_{n}\right\}\right]$ ( $\left.\mathrm{n}=1-8\right)$. The crystal lattice for compounds with $n=4$ or 6 contain independent molecules which show no intra- or inter-molecular Au*AAu interactions. In contrast, the structures of the related gold complexes with shorter or longer chain diphosphines show intra- $(n=1)$ or intermolecular metal-metal interactions and form discrete 
dimers or polymeric chains (49). Analogous structures occur in other diphosphine complexes of the type $\left[\mathrm{AuCl}_{2}\{\mu\right.$ $\left.\left.\left(\mathrm{PPh}_{2}\right)_{2} \mathrm{X}\right\}\right]$. In the complex with $\mathrm{X}=\left(\mathrm{C}=\mathrm{PMe}_{3}\right)$, the diphosphine changes their ground state syn/anti orientation to a symmetrical syn/syn conformation upon coordination to gold(I). From temperature dependent NMR studies the energy of the $\mathrm{Au} \cdots \mathrm{Au}$ interaction has been estimated to be in the order of $29-33 \mathrm{~kJ} / \mathrm{mol}$ (50). There are some examples, such as $\left[\mathrm{Au}(\mathrm{py})_{2}\right]^{+}\left[\mathrm{AuX} \mathrm{X}_{2}\right]^{-}$(28), $\left[\mathrm{Au}\left(\mathrm{PPhMe}_{2}\right)_{2}\right]^{+}\left[\mathrm{Au}\left(\mathrm{GeCl}_{3}\right)_{2}\right]^{-}$or the heteronuclear $[\mathrm{TI}(\mathrm{bipy})]^{+}\left[\mathrm{Au}\left(\mathrm{C}_{6} \mathrm{~F}_{5}\right)_{2}\right]^{-}$(29), that form a chain of four metal atoms, where unexpectedly the sequence of formal charges is -++-, +--+ or +--+, respectively, which is clearly a variance with the simple rules of Coulomb forces (51).

The self-assembly reaction of oligomeric digold(I) diacetylides $\left[\left\{\left(\mathrm{AuC} \equiv \mathrm{CCH}_{2} \mathrm{OC}_{6} \mathrm{H}_{4}\right)_{2} \mathrm{X}\right\}_{n}\right]$ with diphosphines $\mathrm{Ph}_{2} \mathrm{P}\left(\mathrm{CH}_{2}\right)_{n} \mathrm{PPh}_{2}$ leads to the synthesis of organometallic catenanes. Systematic investigations of this unusual reaction have shown that the number of methylene spacer groups $n$ in the diphosphine and the nature of the hinge group $X$ are key factors in determining if the self-assembly will give a simple ring by $1+1$ assembly (30), a [2]catenane by $2+2$

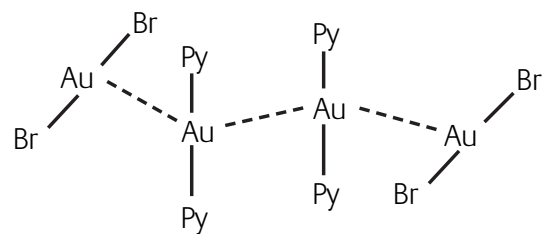

(28)

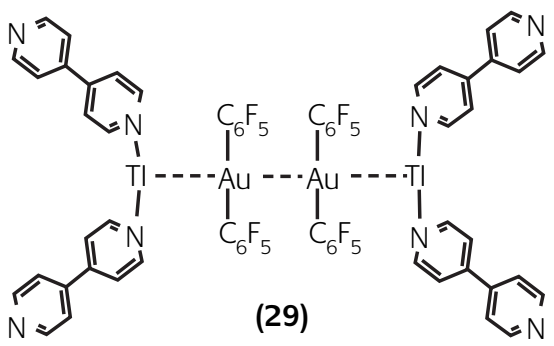

Box 9. Two examples of Gold(I) complexes with interactions between centres with the same formal charge

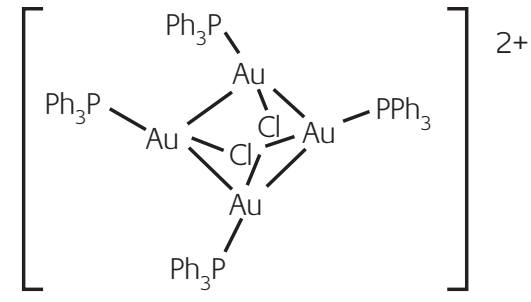

(20)

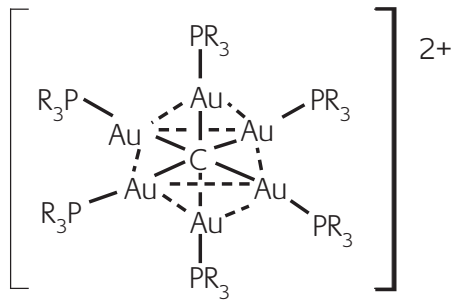

(23)

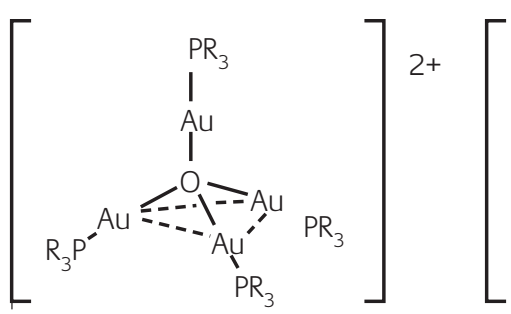

(21)

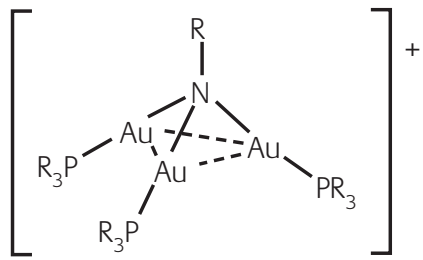

(24)

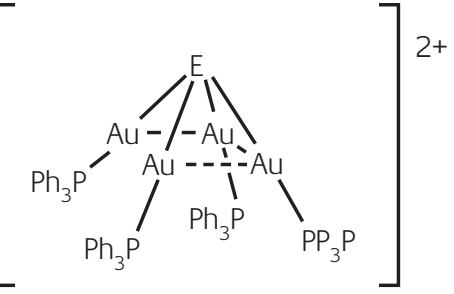

(22)

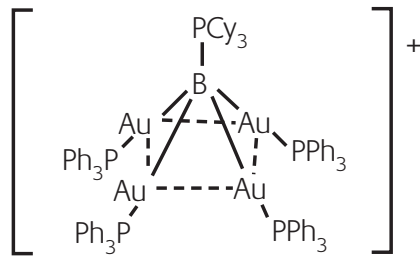

(25)

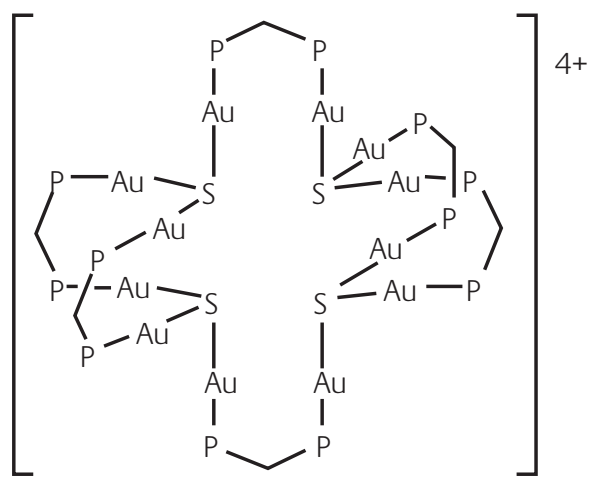

(26)

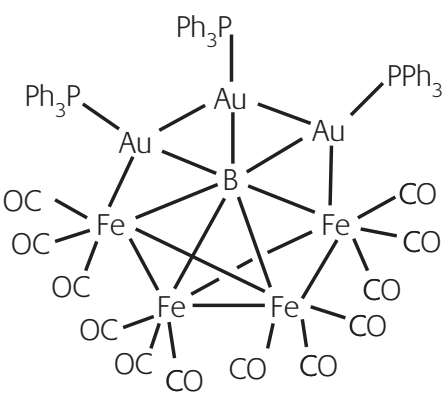

(27)

Box 8. Some examples of polyaurated Gold(I) complexes 
assembly (31), or a double braided [2]catenane by $4+4$ assembly (52). Unsubstituted acetylene and polyines give dinuclear gold acetylides, such as $\left[\mathrm{Au}_{2}(\mathrm{C} \equiv \mathrm{C})\left(\mathrm{PR}_{3}\right)_{2}\right](53)$.

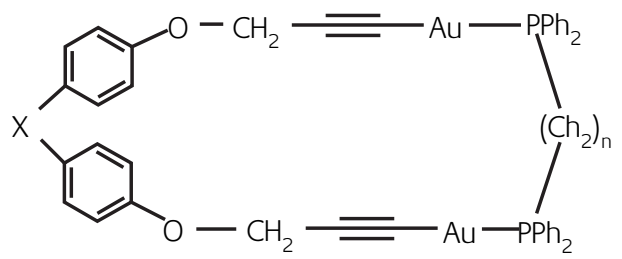

(30)

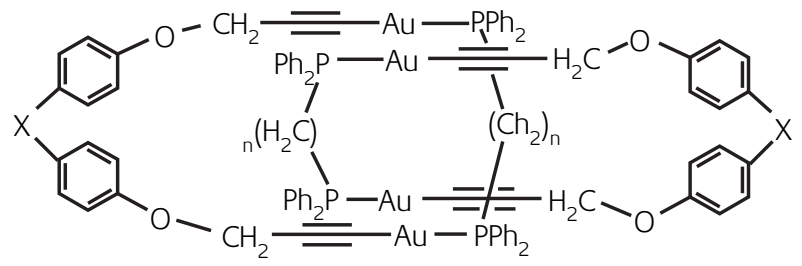

(30)

Box 10. Ring and catenane Gold(I) complexes

Many gold(I) complexes are suspected of having optical properties and consequently in the last years several reports have dealt with luminescence in gold complexes. It has been shown that the luminescence has its origin in the nature of the ligands, in the geometry around the metal centre, and in the presence of metal-metal interactions. In mononuclear gold(I) complexes the luminescence has been associated with a trigonal, non-centrosymmetric structure obtained either through intermetallic interactions or three-coordination associated with a metal centred (MC) $\mathrm{pz} \rightarrow \mathrm{ds}$ phosphorescence (54). Other possible absorption modes, such as ligand centred (LC) or ligand to metal charge transfer (LMCT), are also observed depending upon the types of ligands

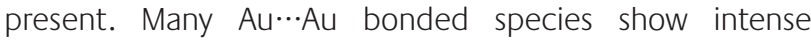
photoluminescence in the UV/VIS region if investigated in the solid state, although this effect may disappear in solution. Some compounds, such as $\left[\mathrm{Au}_{2}\left\{\mathrm{~S}_{2} \mathrm{CN}\left(\mathrm{C}_{5} \mathrm{H}_{11}\right)_{2}\right\}_{2}\right]$, interact in a reversible way with volatile organic compounds (VOC) vapors with a dramatic change in the color and a positive "switching on" of luminescence (55). It has also demonstrated that luminescence of gold complexes can be triggered by solvation of the donor-free solid substrate either from the vapour phase or by dissolving the material in a solvent. Bachman et al have reported the construction of striking "rotator phases" of gold complexes based solely on their metal-metal interactions (56). The complexes $\left[\mathrm{Au}_{2}\left\{\left(\mathrm{PR}_{2}\right)_{2} \mathrm{CH}_{2}\right\}\right]^{2+}(\mathrm{R}=\mathrm{Me}, \mathrm{Ph}, \mathrm{Cy})$ are luminescent in the solid state and in solution, and the high luminescent derivative with $\mathrm{R}=\mathrm{Ph}$ can be used in lightemitting diodes (57). The gold trimer $\left[\mathrm{Au}_{3}(\mathrm{MeN}=\mathrm{COMe})_{3}\right]$ displays the novel phenomenon termed solvo-luminescence. After irradiation with near-uv light, crystals of this compound shows a long-live photoluminescence that is ready detected by the human eye for tens of seconds after cessation of irradiation. Addition of dichloromethane of chloroform to these previously irradiated crystals produces a bright burst of light (58). For this phenomenon the solid state structure is crucial and consists of individual molecules of $\mathrm{Au}_{3} \mathrm{~L}_{3}$ which

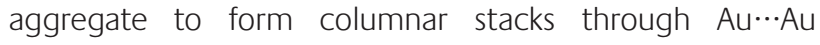
interactions. Other similar complexes, such as $\left[\mathrm{Au}_{3}\left(\mathrm{PhCH}_{2} \mathrm{~N}=\mathrm{COMe}\right)_{3}\right]$ or $\left[\mathrm{Au}_{3}\left(\mathrm{~N}=\mathrm{C}_{5} \mathrm{H}_{4}\right)_{3}\right]$, do not associate into trigonal prismatic array and do not display solvoluminiscence (59). The light sensitivity of some gold compounds has permitted the study of an important number of photochemical reactions (60).

In this area an important work has been developed in goldheterometal complexes (Cu, Ag, TI, Ir, etc) (61). The reaction of basic/donor gold(I) complexes with acid/acceptor complexes gives acid-basic or acceptor-donor derivatives. Thus the treatment of the aurate(I) salts $\left[\mathrm{AuR}_{2}\right]^{-}\left(\mathrm{R}=\mathrm{C}_{6} \mathrm{~F}_{5}, \mathrm{C}_{6} \mathrm{~F}_{3} \mathrm{H}_{2}, \mathrm{C}_{6} \mathrm{Cl}_{5}\right)$ with silver(I) or thallium salts (in the presence of a ligand $L$ ) affords yellow or orange polymers of the type $\left[R_{2} A u(\mu-\right.$ $\left.\mathrm{AgL})_{2} \mathrm{AuR} \mathrm{R}_{2}\right]_{\infty}$ or $\left[\mathrm{R}_{2} \mathrm{AuTI}\right]_{\infty}$ (32). Some or them have solid-state structures that permit reversible interactions and related colour changes with a variety of vapour organic compounds (62). In a similar reaction the trinuclear complexes $\left[\mathrm{Au}_{3}(p-\right.$ $\left.\left.\mathrm{MeC}_{6} \mathrm{H}_{4} \mathrm{~N}=\mathrm{OEt}\right)_{3}\right]$ and $\left[\mathrm{Au}_{3}(\text { bzim) })_{3}\right]$ (bzim = 1 benzylimidazolate), which are colorless, can produce brightly colored materials by sandwiching bare $\mathrm{Ag}^{+}$or $\mathrm{Tl}^{+}$ions from linear-chain complexes (33, M = Ag, Tl) with luminescence properties as luminescence thermochromism (63). Other heteronuclear compounds which present $\mathrm{Au}(\mathrm{I}) \cdots \mathrm{M}$ interactions are well represented in the area of metal carbonyl clusters. The addition of a $\left[\mathrm{AuPR}_{3}\right]^{+}$or $\left[\mathrm{Au}_{2}(\mu-\mathrm{P}-\mathrm{P})\right]_{2}{ }^{+}$fragments to a metal cluster results in the formation of Au-M bonds (complex 34), often with retention of the cluster framework (64).

Some gold hydrides have been described (65). Recent ground-breaking solid-matrix investigations have provided the first experimental evidence for $\left(\mathrm{H}_{2}\right) \mathrm{AuH}$ (66). Complexes with bridging hydride ligands can be prepared by reacting the electrophilic fragment $\left[\mathrm{AuPR}_{3}\right]^{+}$and complexes with terminal M-H bonds (as complexes 34 or 35) (67).

An example of a complex with a formal $\mathrm{Au}(\mathrm{I})-\mathrm{Au}(\mathrm{III})$ bond is $\left[\left\{\mathrm{Au}_{2}\left\{\mu-\left(\mathrm{CH}_{2}\right)_{2} \mathrm{PPh}_{2}\right\}_{2} \mathrm{Au}\left(\mathrm{C}_{6} \mathrm{~F}_{5}\right)_{3}\right]\right.$ (36), which has been obtained by reaction of $\left[\mathrm{Au}_{2}\left\{\mu-\left(\mathrm{CH}_{2}\right)_{2} \mathrm{PPh}_{2}\right\}_{2}\right]$ with $\left[\mathrm{Au}\left(\mathrm{C}_{6} \mathrm{~F}_{5}\right)_{3}\left(\mathrm{OEt}_{2}\right)\right](68)$.

\section{Clusters and gold(0) complexes}

There is an important class of gold compounds in which the formal oxidation state is between 0 and +1 . They can be homo- or hetero-nuclear compounds, for which excellent reviews have been published recently (57). The nuclearity of structurally characterised homonuclear clusters goes from 4 
(some examples of tetra-, as $\left[\mathrm{Au}_{4}\left\{\left(\mathrm{PPh}_{2}\right)_{2} \mathrm{C}_{2} \mathrm{~B}_{9} \mathrm{H}_{10}\right\}_{2} \mathrm{~L}_{2}\right]$ (37), or hexa-nuclear complexes, as $\left[\left(\mathrm{H}_{12} \mathrm{~B}_{10} \mathrm{Au}\right)\left(\mu-\mathrm{AuPEt}_{3}\right)_{4}\left(\mathrm{AuB}_{10} \mathrm{H}_{12}\right)\right](\mathbf{3 8})$ are collected in box 12 (69)) to 39, as the complex $\left[\mathrm{Au}_{39} \mathrm{Cl}_{6}\left(\mathrm{PPh}_{3}\right)_{14}\right] \mathrm{Cl}_{2}$ (39), which has a structure related to a hexagonal packed geometry with a 1:9:9:1:9:9:1 individual layers of gold atoms (box 12) (70). A great effort has been carried out in the characterisation of the cluster $\left[\mathrm{Au}_{55} \mathrm{Cl}_{6}\left(\mathrm{PPh}_{3}\right)_{12}\right]$, obtained by reduction of $\left[\mathrm{AuCl}\left(\mathrm{PPh}_{3}\right)\right]$ with $\mathrm{B}_{2} \mathrm{H}_{6}(71)$.

A large number of mixed metal-gold clusters are known, the metal can vary from an early transition metal, to the platinum group or coinage metals. With coinage metals we must highlight deserves. a novel series of Au-Ag supraclusters whose metal frameworks are based on vertex-sharing polyicosahedron. In the structure of these compounds, the basic building block is the 13-metal atom ( $\left.\mathrm{Au}_{7} \mathrm{Ag}_{6}\right)$ icosahedra. The first member of this series is the 25-metal-atom cluster $\left[\left(\mathrm{Ph}_{3} \mathrm{P}\right)_{19} \mathrm{Au}_{13} \mathrm{Ag}_{12} \mathrm{Br}_{8}\right]^{+}$(40), obtained by reduction of a mixture of $\left[\mathrm{AuX}\left(\mathrm{PR}_{3}\right)\right]$ and $\left[\mathrm{AgX}\left(\mathrm{PR}_{3}\right)\right]$ with $\mathrm{NaBH}_{4}(72)$. Mixed goldplatinum group metal complexes are numerous, amongst them the reactivity of the clusters $\left[\mathrm{M}\left(\mathrm{AuPPh}_{3}\right)_{8}\right]^{2+}(\mathrm{M}=\mathrm{Pd}, \mathrm{Pt})$ (41), synthesised by reduction of mixtures of $\left[\mathrm{M}\left(\mathrm{PPh}_{3}\right)_{4}\right]$ and $\left[\mathrm{Au}\left(\mathrm{NO}_{3}\right)\left(\mathrm{PPh}_{3}\right)\right]$, has been thoroughly studied (73).

Monomeric zerovalent gold complexes are rare. Recently the reduction of gold $(I)$ derivatives with the macrocyclic<smiles></smiles>

(32)

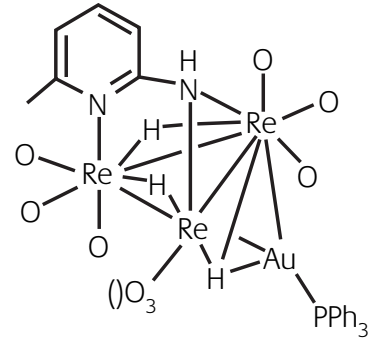

(34)

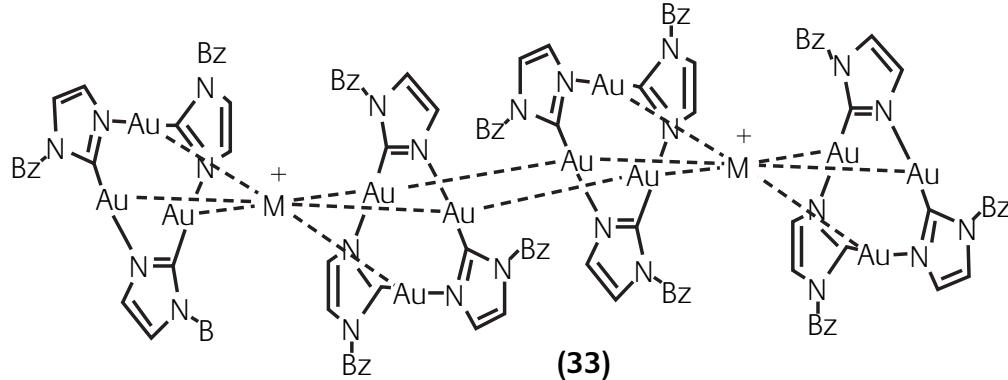

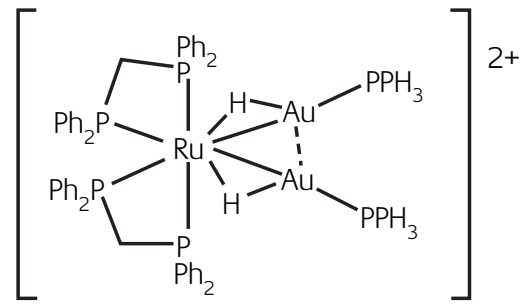

(35)<smiles>FC(F)(F)[Al]([Al]1CP(c2ccccc2)C[Al]1P)(C(F)(F)F)C(F)(F)F</smiles>

(36)

Box 11. Some examples of gold(I)-heterometal complexes

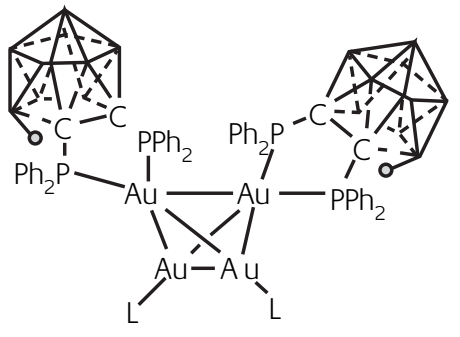

(37)

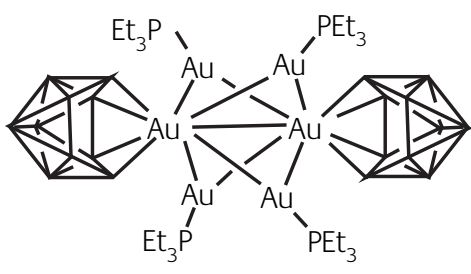

(38)
Au

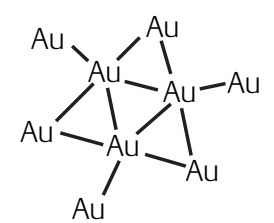<smiles>[AlH]1[AlH][Al]2[AlH][Al]1[AlH]2</smiles>

$\mathrm{Au}$<smiles></smiles>

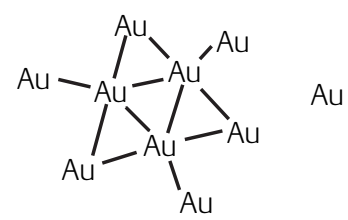

(39. Layers of the cluster $\left.\left[\mathrm{Au}_{39} \mathrm{Cl}_{6}\left(\mathrm{PPh}_{3}\right)_{14}\right] \mathrm{Cl}_{2}\right)$

Box 12. Some examples of homonuclear gold clusters 


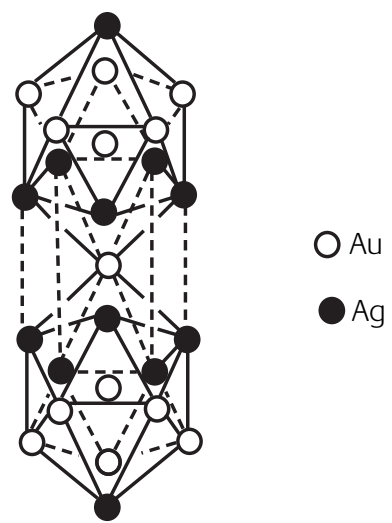

(40. Core of $\left.\left[\left(\mathrm{Ph}_{3} \mathrm{P}\right)_{19} \mathrm{Au}_{13} \mathrm{Ag}_{12} \mathrm{Br}_{8}\right]^{+}\right)$

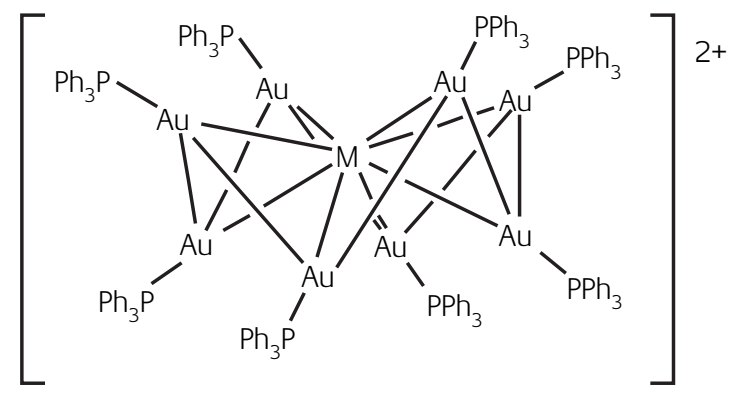

(41)

Box 13. Some examples of heteronuclear gold clusters

silacalix[n]phosphinine ligands has allowed the synthesis of gold(0) derivatives (74). These ligands possess an adequate balance between $\sigma$-donating and $\pi$-accepting properties and then can act as macrocyclic equivalent of carbonyl groups. The reaction of these macrocycles with $\left[\mathrm{AuCl}\left(\mathrm{SMe}_{2}\right)\right]$ in the presence of $\mathrm{GaCl}_{3}$ yields the complexes [AuL] $\left[\mathrm{GaCl}_{4}\right]$. The electrochemical reduction of one of these derivatives allows the synthesis of the gold(0) compound (42).

\section{Gold(-I) compounds}

Gold is unique among the transition metals in its ability to form isolable non-metallic compounds that contain a monoatomic anion. The metal aurides RbAu and CsAu have been known for about half a century, but ( $\left.\mathrm{NMe}_{4}\right) \mathrm{Au}$ (the first compound with a non-metal cation), the ternary auride oxides $\mathrm{M}_{3} \mathrm{AuO}(\mathrm{M}=\mathrm{K}, \mathrm{Rb}, \mathrm{Cs})$ and the aurideaurates $\mathrm{Rb}_{5} \mathrm{Au}_{3} \mathrm{O}_{2}$ and $\mathrm{M}_{7} \mathrm{Au}_{5} \mathrm{O}_{2}(\mathrm{M}=\mathrm{Rb}, \mathrm{Cs})$ have only recently been discovered (75). The gold atoms in $\mathrm{CsAu} \cdot \mathrm{NH}_{3}$ are shifted towards each

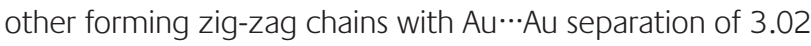
$\AA$. This "auridophilic attraction" takes place between $d^{10} s^{2}$ anions but surprisingly yields a similar distance as the aurophilic attraction in $\mathrm{d}^{10}$ cations (76).

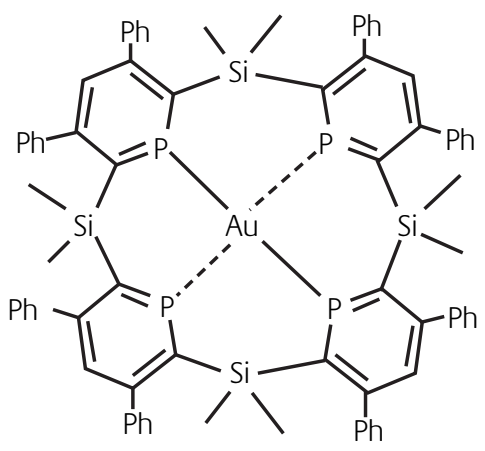

(42)

Box 14. A gold(0) complex

\section{Acknowledgements}

We thank the Dirección General de Investigación Científica y Técnica (Project BQU2001-2409-C02-01) for financial support.

\section{About the Authors}

Dr M. Concepción Gimeno is 'Investigador Científico' at the Instituto de Ciencia de Materiales de Aragón, University of Zaragoza-CSIC. She completed her PhD degree with Professors R. Usón and A. Laguna at the University of Zaragoza (1988). In 1989 she was a postdoctoral fellow at the University of Bristol under the supervision of Professor F.G.A. Stone. She is the author of more than 150 scientific papers on the organometallic and coordination chemistry of silver and gold.

Professor Antonio Laguna completed his PhD degree with Professor R. Usón in 1973. He also completed a postdoctoral period at the University of Bristol in 1975, under the supervision of Professor F.G.A. Stone. Since 1976 he has worked at the University of Zaragoza as Professor Titular and, since 1986, Professor of Inorganic Chemistry. He is the author of more than 270 scientific papers on the organometallic and coordination chemistry of silver and gold.

\section{References}

1 A. Bayler, A. Schier, G.A. Bowmaker and H. Schmidbaur, J. Am. Chem. Soc. 1996, 118, 7006

2 F. Scherbaum, A. Grohmann, B. Huber, C. Krüger and H. Schmidbaur, Angew. Chem. Int. Ed. 1988, 27, 1544

3 P. Pyykkö, Chem. Rev. 1997, 97, 597

4 N. Kaltsoyannis, J. Chem. Soc., Dalton Trans. 1997, 1

5 A.A. Timakov, V.N. Prusakov and Y.V. Drobyshevskii, Dokl. Akad. Nauk SSSR 1986, 291, 125; J.H. Holloway and G.J. Schrobilgen, J. Chem. Soc., Chem. Commun. 1975, 623

6 I.C. Hwang and K. Seppelt, Angew. Chem., Int. Ed., 2001, 40, 3690 
7 M.J. Vasile, T.J. Richardson, F.A. Stevie and W.E. Falconer, J. Chem. Soc., Dalton Trans. 1976, 351

8 O. Graudejus, S.H. Elder, G.M. Lucier, C. Shen and N. Bartlett, Inorg. Chem. 1999, 38, 2503; O. Graudejus, A.P. Wilkinson and N. Bartlett, Inorg. Chem. 2000, 39, 1545

9 A.J. Schultz, H.H. Wang, L.C. Soderholm, T.L. Sifter, J.M. Williams, K. Bechgaard and M.H. Whangbo, Inorg. Chem. 1987, 26, 3757

10 D. Belo, H. Alves, E.B. Lopes, M.T. Duarte, V. Gama, R.T. Henriques, M. Almeida, A. Pérez-Benítez, C. Rovira and J. Veciana, Chem. Eur. J. 2001, 7, 511

11 H.H. Murray, J.P. Fackler Jr, L.C. Porter and A.M. Mazany, J. Chem. Soc., Chem. Commun. 1986, 321; H.H. Murray, L.C. Porter, J.P. Fackler Jr and R.G. Raptis, J. Chem. Soc., Dalton Trans. 1988, 2669; J.P. Fackler Jr, Inorg. Chem. 2003, 42, 1386

12 R.G. Raptis, H.H. Murray, R.J. Staples, L.C. Porter and J.P. Fackler Jr, Inorg. Chem. 1993, 32, 5576

13 E.J. Fernández, M.C. Gimeno, P.G. Jones, A. Laguna, M. Laguna and J.M. López de Luzuriaga, J. Chem. Soc., Dalton Trans. 1992, 3365

14 E.J. Fernández, M.C. Gimeno, P.G. Jones, A. Laguna and E. Olmos, Organometallics 1997, 16, 1130

15 Y. Fuchita, H. leda, Y. Tsunemune, J. Kinoshita-Kawashima and H. Kawano, J. Chem. Soc., Dalton Trans. 1998, 791; J. Vicente, M.T. Chicote, M.I. Lozano, S. Huertas, Organometallics 1999, 18, 753

16 R.G. Buckley, A.M. Elsome, S.P. Fricker, G.R. Henderson, B.R.C. Theobald, R.V. Parish, B.P. Howe and L.R. Kelland, J. Med. Chem. 1996, 39, 5208

17 J.H. Kim and G.W. Everett Jr., Inorg. Chem. 1981, 20, 853

18 J.C. Chambron, V. Heitz, and J.P. Sauvage, New J. Chem. 1997, 21, 237

19 A.M. Brun, A. Harriman, V. Heitz and J.P. Sauvage, J. Am. Chem. Soc. 1991, 113, 8657; K. Kilså, J. Kajanus, A.N. Macpherson, J. Mårtensson and B. Albinsson, J. Am. Chem. Soc. 2001, 123, 3069; L. Flamigni, I.M. Dixon, J.P. Collin and J.P. Sauvage, Chem. Commun. 2000, 2479;

20 M.C. Blanco, E.J. Fernández, P.G. Jones, A. Laguna, J.M. López de Luzuriaga and M.E. Olmos, Angew. Chem. Int. Ed. 1998, 37, 3042; M.C. Blanco, E.J. Fernández, J.M. López de Luzuriaga, M.E. Olmos, O. Crespo, M.C. Gimeno, A. Laguna and P.G. Jones, Chem. Eur. J. 2000, 6, 4116

21 F. Canales, S. Canales, O. Crespo, M.C. Gimeno, P.C. Jones and A. Laguna, Organometallics 1998, 17, 1617

22 M.J. Calhorda, F. Canales, M.C. Gimeno, J. Jiménez, P.G. Jones, A. Laguna and L.F. Veiros, Organometallics 1997, 16, 3837; S. Canales, O. Crespo, M.C. Gimeno, P.G. Jones, A. Laguna and F. Mendizabal, Organometallics 2001, 20, 4812

23 D. Thompson, Gold. Bull. 1998, 31, 12; Gold. Bull. 1998, 31, 111. G. Dyker, Angew. Chem., Int. Ed., 2000, 39, 4237; S.K. Hashmi, Gold. Bull. 2003, 36, 3; S.K. Hashmi, L. Schwarz, J.H. Choi and T.M. Frost, Angew. Chem. Int. Ed. 2000, 39, 2285; S.K. Hashmi, T.M. Frost and J.W. Bats, J. Am. Chem. Soc. 2000, 122, 11553

24 A.J. Blake, R.O. Gould, J.A. Greig, A.J. Holder, T.I. Hyde, M. Schröder, J. Chem. Soc., Chem. Commun. 1989, 876; A.J. Blake, J.A. Greig, A.L. Holder, T.I. Hyde, A. Taylor and M. Schröder; Angew. Chem. Int. Ed. Engl. 1990, 29, 197

25 S.H. Elder, G.M. Lucier, F.J. Hollander and N. Bartlett, J. Am. Chem. Soc. 1997, 119, 1020
26 S. Seidel and K. Seppelt, Science 2000, 290, 117; T. Drews, S. Seidel and K. Seppelt, Angew. Chem. Int. Ed. 2002, 41, 454

27 P. Pyykkö, Science 2000, 290, 64

28 J. Basil, H.H. Murray, J.P. Facker Jr, J. Tocher, A.M. Mazany, B. TrzcinskaBancroft, H. Knachel, D. Dudis, T.J. Delord and D.O. Marler, J. Am. Chem. Soc. 1985, 107, 6908; A. Laguna and M. Laguna, Coord. Chem. Rev. 1999, 193-195, 837

29 M.A. Bennett, S.K. Bhargava, K.D. Griffiths, G.B. Robertson and W.A. Wickramasinghe, Angew. Chem. Int. Ed. 1987, 26, 258; M.A. Bennett, S.K. Bhargava, K.D. Griffiths and G.B. Robertson, Angew. Chem. Int. Ed. 1987, 26, 260; M.A. Bennett, S.K. Bhargava, D.C.R. Hockless, L.L. Welling and A.C. Willis, J. Am. Chem. Soc. 1996, 118, 10469

30 V.W.W. Yam, S.W.K. Choi and K.K: Cheung, J. Chem. Soc., Chem. Commun. 1996, 1173; V.W.W. Yam, C.K. Li, C.L. Chan and K.K. Cheung, Inorg. Chem. 2001, 40, 7054

31 M.C. Gimeno, J. Jiménez, P.G. Jones, A. Laguna and M. Laguna, Organometallics 1994, 13, 2508

32 H.H. Murray, D.A. Briggs, G. Garzon, R.G. Raptis, L.C. Porter and J.P. Fackler Jr, Organometallics 1987, 6, 1992

33 R. Usón, A. Laguna, M. Laguna, J. Jiménez and P.G. Jones, Angew. Chem. Int. Ed. 1991, 30, 198

34 M. Adelhelm, W. Bacher, E.G. Höhn and E. Jacob, Chem. Ber. 1991, 124 1559; H. Willner, J. Schaebs, G. Hwang, F. Mistry, R. Jones, J. Trotter and F. Aubke, J. Am. Chem. Soc. 1992, 114, 8972

35 H. Schmidbaur, Gold Bull. 1990, 23, 1; Interdisc. Sci. Rev. 1992, 17, 213. J.P. Fackler, Jr, Inorg. Chem., 2002, 41, 6959

36 A. Hamel, N.W. Mitzel and H. Schmidbaur, J. Am. Chem. Soc. 2001, 123, 5106

37 H. Schmidbaur, S. Hofreiter and M. Paul, Nature 1995, 377, 503

38 F. Canales, M.C. Gimeno, P.G. Jones and A. Laguna, Angew. Chem. Int. Ed. 1994, 33, 769; S. Canales, O. Crespo, M.C. Gimeno, P.G. Jones and A. Laguna, Chem. Commun. 1999, 679

39 A. Grohmann, J. Riede and H. Schmidbaur, Nature 1990, 345, 140.

40 H. Schmidbaur, G. Weidenhiller and O. Steigelmann, Angew. Chem. Int. Ed. 1991, 30, 433

41 E. Zeller, H. Beruda, A. Kolb, P. Bissinger, J. Riede and H. Schmidbaur, Nature 1991, 352, 141

42 F. Scherbaum, A. Grohmann, B. Huber, C. Krüger and H. Schmidbaur, Angew. Chem. Int. Ed. 1988, 27, 1544

43 A. Sladek, K. Angermaier and H. Schmidbaur, Chem. Commun. 1996, 1959

44 V. Ramamoorthy and R.P. Sharp, Inorg. Chem. 1990, 29, 3336; J.M. López de Luzuriaga, A. Sladek, A. Schier and H. Schmidbaur, Inorg. Chem. 1997, 36, 966

45 J. Vicente, M.T. Chicote, R. Guerrero and P.G. Jones, J. Am. Chem. Soc. 1996, 118, 699

46 A. Blumenthal, H. Beruda and H. Schmidbaur, J. Chem. Soc., Chem. Commun. 1993, 1005

47 V.W.W. Yam, E.C.C. Cheng and K.K. Cheung, Angew. Chem. Int. Ed. 1999, 38, 197; V.W.W. Yam, E.C.C. Cheng and Z.Y. Zhou, Angew. Chem. Int. Ed. 2000, 39, 1683; D. Fenske, T. Langetepe, M.M. Kappes, O. Hampe and P. Weis, Angew. Chem., Int. Ed., 2000, 39, 1857 

$6420 ;$ K.S. Harpp, C.E. Housecroft, A.L. Rheingold and M.S. Shongwe, J. Chem. Soc., Chem. Commun. 1988, 965

49 P.M. Van Calcar, M.M. Olmstead and A.L. Balch, J. Chem. Soc., Chem. Commun. 1995, 1773; Inorg. Chem. 1997, 36, 5231; H. Schmidbaur, A. Wohlleben, F. Wagner, O. Orama and G. Huttner, Chem. Ber. 1977, 119, 1748

50 H. Schmidbaur, W. Graf, W. and G. Müller, Angew. Chem. Int. Ed. 1988, 27, 417

51 W. Conzelmann, W. Hiller and J. Strähle, Z. Anorg. Allg. Chem. 1984, 512, 169; A. Bauer and H. Schmidbaur, J. Am. Chem. Soc. 1996, 118, 5324; E.J. Fernández, P.G. Jones, A. Laguna, J.M. López de Luzuriaga, M. Monge, J. Pérez and M.E. Olmos, Inorg. Chem. 2002, 41, 1056

52 C.P. McArdle, S. Van, M.C. Jennings and R.J. Puddephatt, J. Am. Chem. Soc. 2002, 124, 3959; C.P. McArdle, M.J. Irwin, M.C. Jennings, J.J. Vittal and R.J. Puddephatt, Chem. Eur. J. 2001, 7, 723

53 C.M. Che, H.Y. Chao, V.M. Miskowski, Y. Li and K.K. Cheung, J. Am. Chem. Soc. 2001, 123, 4985; W. Lu, H.F. Xiang, N. Zhu and C.M. Che, Organometallics 2002, 21, 2343

54 Z. Assefa, B.G. McBurnett, R.J. Staples, J.P. Fackler Jr, B. Assmann and K. Angermaier, Inorg. Chem. 1995, 34, 75; Z. Assefa, B.G. McBurnett, R.J. Staples and J.P. Fackler Jr, Inorg. Chem. 1995, 34, 4965

55 M.A. Mansour, W.B. Connick, R. J. Lachicotte, H.J. Gysling and R. Eisenberg, J. Am. Chem. Soc., 1998, 120, 1329

56 R.E. Bachman, M.S. Fioritto, S.K. Fetics and T.M. Cocker, J. Am. Chem. Soc. 2001, 123, 5376

57 W.F. Fu, K.C. Chan, V.M. Miskowski and C.M. Che, Angew. Chem. Int. Ed 1999, 38, 2783; H.X. Zhang and C.M. Che, Chem. Eur. J. 2001, 7, 4887; Y. Ma, C.M. Che, H.Y. Chao, X. Zhou, W.H. Chan and J. Shen, Adv. Mater. 1999, 11, 852

58 J.C. Vickery, M.M. Olmstead, E.Y. Fung and A.L. Balch, Angew. Chem. Int. Ed. 1997, 36, 1179; E.Y. Fung, M.M. Olmstead, J.C. Vickery and A.L. Balch, Coord. Chem. Rev. 1998, 171, 151

59 A.L. Balch, M.M. Olmstead and J.C. Vickery, Inorg. Chem. 1999, 38 3494; M.M. Olmstead, F. Jiang, S. Attar and A.L. Balch, J. Am. Chem. Soc. 2001, 123, 3260; A. Hayashi, M.M. Olmstead, S. Attar and A.L. Balch, J. Am. Chem. Soc. 2002, 124, 5791

60 A. Vogler and H. Kunkely, Coord. Chem. Rev., 2001, 219-221, 489.

61 E.J. Fernández, A. Laguna and J.M. López de Luzuriaga, Gold Bull. 2001, 34, 14

62 E.J. Fernández, M.C. Gimeno, A. Laguna, J.M. López de Luzuriaga, M. Monge, P. Pyykkö and D. Sundholm, J. Am. Chem. Soc. 2000, 122,
7287; E.J. Fernández, J.M. López de Luzuriaga, M. Monge, M.E. Olmos, J. Pérez, A. Laguna, A.A. Mohamed and J.P. Fackler, J. Am. Chem. Soc., 2003, 125, 2022

63 A. Burini, J.P. Fackler Jr, R. Galassi, B.R. Pietroni and R.J. Staples, Chem. Commun. 1998, 95; A. Burini, R. Bravi, J.P. Fackler Jr, R. Galassi, T.A. Grant, M.A. Omary, B.R. Pietroni and R.J. Staples, Inorg. Chem. 2000, 39, 3158

64. L.H. Pignolet and D.A. Krogstad and P.J. Dyson and D.M.P. Mingos, In Gold, Progress in Chemistry, Biochemistry and Technology. H. Schmidbaur, Ed., 1999, John Wiley \& Sons, Chichester, England, 429 and 511

65 M.J. Crawford and T.M. Klapotke, Angew. Chem., Int. Ed., 2002, 41, 2269

66 X. Wang and L. Andrews, J. Am. Chem. Soc. 2001, 123, 12899

67 B.D. Alexander, B.J. Johnson, S.M. Johnson, A.L. Casalnuovo and L.H. Pignolet, J. Am. Chem. Soc. 1986, 108, 4409; J.A. Cabeza, V. Riera, R. Trivedi and F. Grepioni, Organometallics 2000, 19, 2043

68 R. Usón, A. Laguna, M. Laguna, M.T. Tartón and P.G. Jones, J. Chem. Soc., Chem. Commun. 1988, 740

69 O. Crespo, M.C. Gimeno, P.G. Jones, A. Laguna and M.D. Villacampa, Angew. Chem. Int. Ed. 1997, 36, 993; A.J. Wynd, S.E. Robins, D.A. Welch and A.J. Welch, J. Chem. Soc., Chem. Commun. 1985, 819

70 B.K.Teo, X. Shi and H. Zhang, J. Am. Chem. Soc. 1992, 114, 2743

71 C. Schmid, R. Pfeil, R. Boese, F. Bandermann, S. Meyer, G.H.M. Calis and J.W.A. Van der Velden, Chem. Ber. 1981, 114, 3634; G. Schmid, Inorg. Synth. 1990, 27, 214

72 B.K. Teo and K. Keating, J. Am. Chem. Soc. 1984, 106, 2224; B.K. Teo, X. Shi and H. Zhang, J. Am. Chem. Soc. 1991, 113, 4329; J. Chem. Soc., Chem. Commun. 1992, 1195

73 J.J. Steggerda, Comments Inorg. Chem. 1990, 11, 113; L.N. Ito, B.J. Johnson, A.M. Mueting and L.H. Pignolet, Inorg. Chem. 1989, 28 , 2026; L.N. Ito, A.M.P. Felicissimo and L.H. Pignolet, Inorg. Chem. 1991, 30, 988

74 N. Mézailles, N. Avarvari, N. Maigrot, L. Ricard, F. Mathey, P. Le Floch, L. Cataldo, T. Berclaz and M. Geoffroy, Angew. Chem. Int. Ed. 1999, 38, 3194

75 C. Feldman and M. Jansen, Angew. Chem. Int. Ed. 1993, 32, 1049; A.V. Mudring and M. Jansen, Angew. Chem. Int. Ed. 2000, 39, 3066; P.D.C. Dietzel and M. Jansen, Chem. Commun. 2001, 2208

76 A.V. Mudring, M. Jansen, J. Daniels, S. Krämer, M. Mehring, J.P. Prates Ramalho, A.H. Romero and M. Parrinelo, Angew. Chem. Int. Ed. 2002, 41, 120 